\title{
CORRELATION ANALYSIS BETWEEN THE SERVICE QUALITY, CUSTOMER SATISFACTION, AND CUSTOMER LOYALTY OF VIVA GENERIK PHARMACY IN SEMARANG
}

\section{ANALISIS HUBUNGAN ANTARA KUALITAS PELAYANAN, KEPUASAN KONSUMEN DAN LOYALITAS KONSUMEN APOTEK VIVA GENERIK DI SEMARANG}

\author{
Eva Monica $^{1 *)}$, Basu Swastha Dharmmesta ${ }^{2}$, Suci Paramitasari Syahlani ${ }^{2}$ \\ ${ }^{1}$ Program Studi Farmasi, Fakultas Sains dan Teknologi, Universitas Ma Chung \\ ${ }^{2}$ Program Pascasarjana Fakultas Farmasi, Universitas Gadjah Mada
}

Received June 13, 2017; Accepted October 21, 2017

\begin{abstract}
Today, pharmacy service has become more developed along with the enhancement of society awareness of the importance of health. Therefore, as one of the health service facilities, pharmacy is required not only to give priority on product prices and varieties but also to provide qualified service for the patients. Viva Generik pharmacy as a new comer should have the ability to understand the situation and should have the competitive advantage. This study used a survey method. Data were collected with a purposive sampling method using the instrument of closed questionnaires. The questionnaires were tested for the validity and the reliability to 40 respondents who were the consumers of Viva Generik pharmacy. Questionnaires were given to 150 respondents, then were analyzed using qualitative descriptive statistics to identify the respondents' characteristic. Quantitative analysis was used to identify the quality of the service and to see the correlation between service quality, satisfaction, and customer loyalty of Viva Generik pharmacy. As a result, Viva Generik pharmacy's consumers tended to agree that the quality of service given by Viva Generik pharmacy was good. Simultaneously, service quality variables gave a positive impact to the customer satisfaction and the customer loyalty. It was just the tangible dimension that gave the significant impact on the customer satisfaction and customer loyalty. It was also disclosed that the customer satisfaction brought a significant impact on the customer loyalty to Viva Generik pharmacy.
\end{abstract}

Keywords: customer satisfaction, loyalty, Viva Generik, service quality

\begin{abstract}
ABSTRAK
Pelayanan kefarmasian saat ini telah semakin berkembang seiring dengan peningkatan kesadaran masyarakat akan pentingnya kesehatan. Oleh karena itu apotek sebagai salah satu sarana pelayanan kesehatan akan dituntut tidak hanya mengedepankan sisi produk saja terkait harga dan kelengkapannya, lebih dari itu pelayanan akan menjadi tuntutan bagi pasien. Apotek Viva Generik sebagai pendatang baru harus dapat memahami situasi dan mempunyai suatu keunggulan bersaing (competitive advantage). Kualitas pelayanan yang baik akan berdampak pada kepuasan konsumen, sehingga perlu dievaluasi sejauh mana konsumen puas terhadap pelayanan apotek sehingga apotek Viva Generik sebagai pendatang baru dapat merebut pasar dan mempunyai keunggulan bersaing. Penelitian ini menggunakan metode survei. Data dikumpulkan dengan metode purposive sampling menggunakan alat penelitian berupa kuesioner tertutup. Kuesioner diuji validitas dan reliabilitas terhadap responden yang merupakan
\end{abstract}


pelanggan Apotek Viva Generik. Kuesioner diberikan kepada 150 responden, kemudian dianalisis deskriptif kualitatif untuk mengetahui karakteristik responden. Analisis kuantitatif untuk mengetahui kualitas pelayanan, serta mengetahui hubungan kualitas pelayanan terhadap kepuasan dan loyalitas konsumen Apotek Viva Generik. Hasil penelitian menunjukkan bahwa konsumen apotek Viva Generik cenderung setuju bahwa kualitas pelayanan yang diberikan apotek Viva Generik baik. Variabel kualitas pelayanan secara bersama-sama berpengaruh signifikan positif pada kepuasan konsumen apotek Viva Generik dan juga pada loyalitas konsumen. Namun hanya dimensi tangible yang memberikan pengaruh signifikan pada kepuasan konsumen dan loyalitas konsumen. Diketahui juga bahwa kepuasan konsumen berpengaruh signifikan terhadap loyalitas konsumen Apotek Viva Generik.

Kata kunci: kepuasan konsumen, loyalitas, Viva Generik, kualitas pelayanan

\section{INTRODUCTION}

The rapid growing number of the pharmacy in Indonesia improved the tight competition among the pharmacies, as there were many chain pharmacy franchises such as K-24 and Kimia Farma Pharmacy. These pharmacy outlets have many competitive advantages such as the established system, strong financial support, and good information technology, and strong bargaining power to the medicine distribution and producers that they could provide the complete varieties of medicine in affordable price (Hartono, 2011).

In line with the environmental changes and the existing competition, the Viva Generik, as the new comer, should be able to understand the situation and to have a competitive advantage. In facing the development of the health industries and the society's perspective, pharmacy business owners should have the competitive advantage to survive. Providing the good service quality to the consumers is one of the competitive advantages for the pharmacy. The bad pharmacy service would disadvantage the pharmacy from the side of business because the consumers would move to the other place (Handayani et.al., 2009).

According to Parasuraman et al. (1994), the service quality consists of five dimensions, namely, tangibles, reliability, responsiveness, assurance, the empathy. SERVQUAL is the concept of the service quality based on the difference between the consumerperception of service performance and the consumerexpectation (Parasuraman et al., 1988), while SERVPERF is the approach to measure the service quality based purely on the service performance (Cronin and Taylor, 1992). SERVQUAL and SERVPERF are the most commonly used measure scales of the service quality (Gilmore and McMullan, 2009 in Rodrigues et al., 2010), yet between the two, the SERVQUAL is more commonly used (Duff and Hair, 2008 dan Ladhari, 2009 in Rodrigues et al., 2010). Cronin and Taylor (1992) found that their SERVPERF measurement gave better result than SERVQUAL measurement.

Costumer satisfaction, according to Assael (2001, cited Dewi, 2010) was a positive attitude toward the repeated purchase of the same brand. Hanna dan Woznich (2001, cited in Dewi, 2010) defined the satisfaction as a mental statement on the fair appreciation that was given by the consumer in buying the product. While Engel et al., (1995, cited in Dewi, 2010) defined satisfaction as an evaluation after consuming a product or service on the product or service capability to either meet or exceed the expectation.

Griffin (2005) puts forward that the customer loyalty was a strong commitment of the consumers to make the repeated purchase of the favorite goods or services consistantly in the long term without being influenced by the external factors like the marketing efforts of the other producers. So, the customer loyalty could be defined as a commitment 
attitude to always use the goods or services of the certain producer.

Hill (cited in Rizan, 2010) defines customer loyalty as the behavior that was shown to purchase on the ground of routine units of decision making. According to Cronin dan Taylor (1992), there was a positive correlation between service quality, satisfaction, and customer loyalty, especially in terms of the repeated purchase. Fornell (1992, cited in Bastos dan Gallego, 2008) found a correlation between the perceived service quality and the satisfaction. Cronin and Taylor (1992) found the strong and positive causal relationship beetween the service quality as a whole and satisfaction. Bastos and Galego (2008) examined that there was a positive and significant correlation between the dimensions of service quality, reliability, assurance, and empathy toward consumers.

The correlation between the evaluation of service quality and loyalty was the thing that had not been explored (Bloemer et al., 1999, cited in Rodrigues 2010). Dharmayanti (2006) said that the service quality had direct strong influence on loyalty. In other research, Lei and Jolibert (2012) also mentioned that the service quality had an equivalent impact on the customer loyalty. The correlation between satisfaction and loyalty had been observed in some research. Bowen and Chen (2012) examined that a little change on the satisfaction could cause big changes in the loyalty, while other research disclosed that the customer satisfaction had an influence toward the customer loyalty.

\section{METHODS}

The samples of the research were the consumers of Viva Generik Pharmacy. The number of respondents was 150 individuals selected using non-probability sampling with purposive sampling which was based on the certain consideration and the defined criteria (Sekaran, 2003). The data were obtained from the respondents by distributing the questionnaires which were then analysed to identify the service quality on the ground of the dimensions of tangibles, reliability, responsiveness, assurance, and empathy. The analysis to identify the correlation between service quality and customer satisfaction and loyalty to Viva Generik Pharmacy was carried out using a linear regression.

\section{RESULTS AND DISCUSSION The Result of Validity and Reliability Testing}

In the validity testing of the questionnaires, it was found out that the Kaiser-Meyer-Olkin (KMO) score was 0.705 with Chi Square score of 3810.201 and the significance score of 0.000 so that it could be proceeded with the factor analysis. The result was that there were some instrument items which should be taken out from the research model because they did not match any factors. The items that could well match one factor was the items of responsiveness which consisted of three questions. The rotation was only conducted once because the anti image correlation score at $>0.5$ showed that no more items should be taken out.

The reliability testing resulted in a Cronbach's Alpha score for all question constructs which was bigger than 0.70 , hence all the existing constructs were assumed to be reliable. Therefore, it could be concluded that all the measuring instruments used in this reserach were consistent, and reliable and also feasible for the double regression testing. Table I presented the respondent characteristics such as sex, ages, education level, occupation, and number of visit.

\section{The Analysis of the Descriptive Statistics}

Table II showed that the respondents were likely to agree to the items of the tangibles, reliability, responsiveness, assurance, and empathy which meant that Viva Generik Pharmacy provided good service quality to the consumers. And they did so to the varibles of satisfaction dan loyalty. 
Table I. The Description of the Respondent Characteristics

\begin{tabular}{|c|c|c|c|}
\hline Characteristics & & $\mathrm{N}$ & $\%$ \\
\hline \multirow{2}{*}{ Sex } & Male & 71 & 47.33 \\
\hline & Female & 79 & 52.67 \\
\hline \multirow{5}{*}{ Age } & $<18$ & 2 & 1.33 \\
\hline & $18-30$ & 31 & 20.67 \\
\hline & $31-40$ & 41 & 27.33 \\
\hline & $41-50$ & 43 & 28.67 \\
\hline & $>50$ & 33 & 22.00 \\
\hline \multirow{7}{*}{ Education Level } & No schooling & 0 & 0.00 \\
\hline & Elementary School Level & 2 & 1.33 \\
\hline & Junior High School Level & 8 & 5.33 \\
\hline & Senior High School Level & 49 & 32.67 \\
\hline & Non University Diploma & 14 & 9.33 \\
\hline & Under Graduate University Level & 65 & 43.33 \\
\hline & Graduate University Level & 12 & 8.00 \\
\hline \multirow{7}{*}{ Occupation } & Military/Police Officers & 1 & 0.67 \\
\hline & Civil Servant & 5 & 3.33 \\
\hline & Private Sector Worker & 75 & 50.00 \\
\hline & Farmer/Labour & 4 & 2.67 \\
\hline & $\begin{array}{l}\text { Business Owner/Entrepreneurs/ } \\
\text { Traders }\end{array}$ & 37 & 24.67 \\
\hline & The Retired & 8 & 5.33 \\
\hline & Others & 20 & 13.33 \\
\hline \multirow{3}{*}{ Number of Visit } & 1-2 times & 0 & 0.00 \\
\hline & 3-5 times & 38 & 25.33 \\
\hline & $>5$ times & 112 & 74.67 \\
\hline
\end{tabular}

Table II. The Result of Descriptive Statistics Analysis

\begin{tabular}{lccccc}
\hline \multicolumn{1}{c}{ Variable } & N & Minimum & Maximum & Mean & $\begin{array}{c}\text { Standard } \\
\text { Deviation }\end{array}$ \\
\hline Tangibles & 150 & 3.000 & 5.000 & 3.962 & 0.334 \\
Reliability & 150 & 3.600 & 5.000 & 4.048 & 0.239 \\
Responsiveness & 150 & 2.670 & 5.000 & 4.056 & 0.295 \\
Assurance & 150 & 2.500 & 5.000 & 3.971 & 0.301 \\
Empathy & 150 & 3.500 & 5.000 & 4.024 & 0.245 \\
Satisfaction & 150 & 3.000 & 5.000 & 4.378 & 0.440 \\
Loyalty & 150 & 2.230 & 4.230 & 3.694 & 0.270 \\
\hline
\end{tabular}

The Analysis of the Correlation between Service quality and Customer satisfaction of Viva Generik Pharmacy

The correlation between service quality and costumer satisfaction could be seen from Table III. The score of $\mathrm{R}^{2}$ at 0.275 which meant that about $27 \%$ of the costumer satisfaction was influenced by the above 5 dimensions, while the rest, $(100 \%-27 \%=$ $73 \%$ ), namely $73 \%$, was influenced by other reasons outside the model. The $\mathrm{F}$ score calculation at 10.903 with the significance score at 0.000 was smaller than 0.05 so that
Ho 1 was rejected and Ha 1 was accepted, which meant that the service quality (tangibles, reliability, responsiveness, assurance, and emphaty) had positive influence on the Viva Generik Pharmacy customer satisfaction.

From Table IV, the regression equation could be formulated as follows:

$\mathrm{Y}=0.570 \mathbf{X}_{1}-0.157 \mathbf{X}_{2}-0.102 \mathbf{X}_{3}+0.078 \mathbf{X}_{4}-0.086 \mathbf{X}_{5}$

The service quality dimension which had partial influence on the customer satisfaction was the dimension of tangibles; whereas the 
other dimensions, namely reliability, responsiveness, assurance, and emphaty had insignificant influence on customer satisfaction.

\section{The Correlation Analysis between Service Quality and Customer Loyalty of Viva Generik Pharmacy}

Table $\mathrm{V}$ presented the analysis testing result of coefficient of determination and the analysis result of the f-test for service quality to the customer loyalty. In the F-Test regression testing, it was known that the $\mathrm{F}$ score was 4.003 with the significance at 0.002 which was smaller than 0.005 , hence Ho2 was rejected and $\mathrm{Ha} 2$ was accepted, which meant that the service quality as a whole had the significant influence on customer loyalty. The coefficient of determination score ( $\mathrm{R}$ square) indicated the model capability in explaining the dependent variables. The score 0.122 meant that about $12 \%$ of customer loyalty was influenced by the above 5 dimensions, while the rest $(100 \%-12 \%=88 \%)$, that was $88 \%$, was influenced by the other reasons outside of the model.

From Table VI, the regression equation could be formulated as follows:

$\mathbf{Z}=0.281 \mathbf{X}_{1}+0.203 \mathbf{X}_{2}-0.134 \mathbf{X}_{3}-0.073 \mathbf{X}_{4}+0.013 \mathbf{X}_{5}$

The dimension of the quality which partially had signifiant influence on the customer loyalty was the dimension of tangibles. The dimension of tangibles gave the influence on the customer loyalty at 0.281 .

Table III. The Analysis Testing Result of Coefficient of Determination and the Analysis Result of the F-Test for the Service Quality to Customer satisfaction

\begin{tabular}{lllll}
\hline Model & $\mathrm{R}$ & $\mathrm{R}^{2}$ & $\mathrm{~F}$ & Sig. \\
\hline 1 & $0.524^{\mathrm{a}}$ & 0.275 & 10.903 & 0.000 \\
\hline
\end{tabular}

Table IV. The Result Analysis of the T-Test of Service quality toward Customer satisfaction

\begin{tabular}{lllll}
\hline Variable & Reg & T-Calculation & Significance & Conclusion \\
& Coefficient & & & \\
\hline Tangibles & 0.570 & 7.271 & 0.000 & Hola was rejected \\
Reliability & -0.157 & 0.943 & 0.347 & Holb was accepted \\
Responsiveness & -0.102 & -1.052 & 0.294 & Holc was accepted \\
Assurance & 0.078 & -1.574 & 0.118 & Hold was accepted \\
Empathy & -0.086 & -0.931 & 0.354 & Hole was accepted \\
\hline
\end{tabular}

Table V. The Analysis Testing Result of Coefficient of Determination and the Analysis Result of the F-Test for Service Quality to the Customer Loyalty

\begin{tabular}{lllll}
\hline Model & $\mathrm{R}$ & $\mathrm{R}^{2}$ & $\mathrm{~F}$ & Sig. \\
\hline 2 & 0.349 & 0.122 & 4.003 & 0.002 \\
\hline
\end{tabular}

Table VI. The Result Analysis of the T-Test of Service quality toward Customer loyalty

\begin{tabular}{lllll}
\hline Variable & Reg & T-Calculation & Significance & Conclusion \\
& Coefficient & & & \\
\hline Tangibles & 0.281 & 3.257 & 0.001 & Ho2a was rejected \\
Reliability & 0.203 & -0.807 & 0.421 & Ho2b was accepted \\
Responsiveness & -0.134 & -1.250 & 0.213 & Ho2c was accepted \\
Assurance & -0.073 & 1.853 & 0.066 & Ho2d was accepted \\
Empathy & 0.013 & 0.131 & 0.896 & Ho2e was accepted \\
\hline
\end{tabular}

Table VII. The Analysis Result of the Coefficient of Determination Testing and the Analysis F-Test of Satisfaction

\begin{tabular}{llll}
\multicolumn{4}{c}{ toward Loyalty } \\
\hline Dimension & Reg. Coef. & t & Sig. \\
\hline Patients' Satisfaction & 0.288 & 3.655 & 0.000
\end{tabular}




\section{The Correlation Analysis between Customer satisfaction and the Viva Generik Pharmacy Customer Loyalty}

From Table VII, the regression equation could be formulated as follows:

\section{$\mathbf{Z}=0.288 \mathbf{Y}$}

The variable of satisfaction was significant because based on the result of the above T-test, the significance value at 0.000 was smaller that 0.05 , therefore the Hypothesis $\mathrm{Ho} 3$ was rejected and $\mathrm{Ha} 3$ was accepted and hence the customer satisfaction had positive influence on loyalty.

\section{CONCLUSION}

The varibles of the service quality as a whole had the positive influence on the Viva Generik Pharmacy customer satisfaction and the dimension of tangibles had significant influence on the Viva Generik Pharmacy customer satisfaction. The variables of service quality as a whole had a positive influence on the Viva Generik Pharmacy customer loyalty. The dimension which had significant influence statistically on the Viva Generik Pharmacy customer loyalty was the tangibles. Based on the satisfaction analysis to the Viva Generik Pharmacy customer loyalty, the positive beta score was found and was significant between the variables of satisfaction and loyalty.

From the obtained data, the researchers give the suggestion to the marketing section to implement more effective strategies in improving the service quality, especially in the dimensions of reliability, responsiveness, assurance and empathy, which emphasize on the ability to meet the promised accurate service. In addition, the medicine availability and the individual attentive service should also be improved. It should also evaluate the medicine availability, especially the ones that were often demanded by consumers, and it should provide a sustainable training for the employees so that the service provided by the pharmacy to every consumer could well be perceived and the consumers could feel satisfied. It should also improve the CRM service (by phone call) of Viva Generik Pharmacy by providing patients and consumers house calls, especially to those who suffer from degenarative diseases. This service aimes at monitoring the medicine usage by the patients to achieve the medication objectives. The evaluation should be held once in three months to appraise whether the employees have implemented good service quality, particularly in the four dimensions.

\section{ACKNOWLEDGEMENT}

The gratitude goes to the Viva Generik Pharmacy and all the apothecaries and employees who gave permission and facilitated the research implementation.

\section{REFERENCES}

Bastos, J., Gallego, P.M., 2008. Pharmacies Customer Satisfaction and Loyalty - A Framework Analysis. Document de Trabajo Nuevas Tendencias En Direccion De Empresas, 7, 1-30.

Bowen, J.T., Chen, S.L., 2001. The Relationship between Customer Loyalty and Customer Satisfaction. International Journal of Contemporary Hospitality Management, 13 (5), 213217.

Cronin, J.J., Taylor, S.A., 1992. Measuring service quality: A Reexamination and Extension. Journal of Maketing, 56, 55-58.

Dewi, S.A., 2010. Variety Seeking sebagai Variabel Moderator Pengaruh Corporate Image dan Customer Satisfaction pada Customer Loyalty. Jurnal Bisnis dan Manajemen, 10, 118.

Dharmayanti, D., 2006. Analisis Dampak Service Performance dan Kepuasan sebagai Moderating Variable Terhadap Loyalitas Nasabah. Jurnal Manajemen Pemasaran, 1 (1), 35-43. 
Griffin, J., 2005. Customer Loyalty. Menumbuhkan dan Mempertahankan Kesetiaan Pelanggan, Erlangga, Jakarta.

Handayani, R.S., Raharni, Gitawati, R., 2009. Persepsi Konsumen Apotek Terhadap Pelayanan Apotek di Tiga Kota di Indonesia. Makara Kesehatan, 13 (1), 22-26.

Lei, P., Jolibert, A., 2012. A Three-Model Comparison of the Relationship between Quality, Satisfaction, and Loyalty: an Empirical Study of the Chinese Healthcare System. Health Service Research, 12, 436.

Parasuraman, A., Zeithaml, V.A., Berry, L.L., 1988. Servqual. A Multiple-item Scale for Measuring ConsumerPerceptions of
Service Quality. Journal of Retailing, 64, 12-40.

Rizan, M., 2010. Analysis of Service Quality on Customer Satisfaction and its Influence on Customer Loyalty: Passengers Survey of Domestic Full Service Airlines Company "Garuda Indonesia" in Indonesia. Oxford Business and Economic Conference Program, Juni 28-29.

Rodrigues, L.L.R., Barkur, G., Varambally, K.V.M., Motlagh, F.G., 2010. Comparison of SERVQUAL and SERVPERF metrics: an empirical study. The TQM Journal, 23 (6), 629643.

Sekaran, U., 2003. Research Methods for Business: A Skill Building Approach, John Wiley and Son Inc., New York. 